\title{
Empirical analysis of the push factors of human capital flight in Nigeria
}

\author{
Oluwaseyi Popogbe and Oluyemi Theophilus Adeosun \\ Department of Economics, University of Lagos, Lagos, Nigeria
}

\begin{abstract}
Purpose - Human capital flight from Nigeria to developed countries has remained a topical issue. This paper aims to empirically analyze the push factors for the migrants who explore the various legal migrant schemes from a macro perspective. The authors examine human capital development and its role in contributing to human capital flight to more developed counties.
\end{abstract}

Design/methodology/approach - This paper is anchored on the push-pull model. Using secondary data from 1990 to 2019, the authors look at the relationship between human capital flight and variables such as life expectancy, infant mortality rate, population growth rate and Nigeria's unemployment rate. The auto-regressive lag model (ARDL) was adopted to estimate the empirical relationship among these variables.

Findings - The results from the ARDL model suggest a positive relationship exists between population growth rate and migration rate. A negative relationship was, however, observed between life expectancy and migration rate. This study also found that an increase in the infant mortality rate negatively impacted migration significantly. Therefore, an increase in infant mortality rate lowered the migration rate. Finally, an increase in the unemployment rate increased migration; however, insignificantly.

Research limitations/implications - The findings from this study are limited to the push factors influencing migration out of Nigeria. These factors are also restricted to variables for which data can be derived under the study's scope. The results of this study have far-reaching implications, especially for policymakers and citizens alike. Better human capital development through enhanced life expectancy and reduced population in Nigeria will reduce the migration rate. Therefore, this study calls for the doubling of developmental and infrastructural efforts at all levels of governance.

Originality/value - This paper's importance lies in its ability to elucidate push factors that influenced migration out of Nigeria empirically. An empirical approach to the subject matter will explain these factors and the degree to which they influence migration. This will guide the policy-making process in curbing brain drain, which is a major challenge in Nigeria.

Keywords Migration, ARDL model, Population growth, Human capital flight, Push factors

Paper type Research paper

(C) Oluwaseyi Popogbe and Oluyemi Theophilus Adeosun. Published in Journal of Humanities and Applied Social Sciences. Published by Emerald Publishing Limited. This article is published under the Creative Commons Attribution (CC BY 4.0) licence. Anyone may reproduce, distribute, translate and create derivative works of this article (for both commercial and non-commercial purposes), subject to full attribution to the original publication and authors. The full terms of this licence maybe seen at http://creativecommons.org/licences/by/4.0/legalcode

JEL classification - F22, J60, J61, J62, O15

The authors acknowledge everyone who have contributed to the great success of this research work. Special thanks to Owolabi Kayode and Dr Omolara Morounkeji Faboya for their contributions towards the research.

Human capital

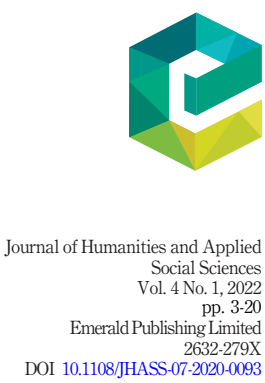




\section{JHASS 4,1}

\section{Introduction}

The practice of migration has been noted to be a part of humanity over the centuries. Scholars have noted that people migrate for different reasons such as economic, political, family, educational, medical, career and search for greener pastures or better quality of life (Thinh, 2017; Light et al., 2017; Okafor and Chimereze, 2020). This phenomenon is not limited to gender, age or educational attainment; as male and female, old and young, learned and unlearned engage in this act. In fact, Orji and Agu (2018) opined that emigrants' characteristics and distribution differ across countries and regions. Recently, it has been discovered that youths' huge desire, including those who are gainfully employed, unemployed or underemployed, to exit developing and developed countries (Dako-Gyeke, 2016; Lemmermann and Riphahn, 2018). The belief among the old and young alike that a good life exists only outside Nigeria, and therefore, leaving the country's shores has emerged as a trending culture (Roman and Vasilescu, 2016; Liu et al., 2018).

Human capital flight remains a major concern in developing counties and in Nigeria in particular. Furthermore, developing countries already have poor human development indices, and further migration of human resources will continue to suppress the country (Ita, 2020). Although it is true that economically, the country is hash, however, the trend by the youths rushing to leave Nigeria goes beyond this singular reason (Komolafe, 2002; Amrevurayire and Ojeh, 2016; Akanle et al., 2019; Okunade, 2019). The rise in the increase of exit or intention to migrate is not unconnected with several indices. Some of these factors include poor state of health in the country, high level of unemployment $(18.8 \%$ in the third quarter 2017) and rising poverty rate in the country ( $80 \%$ below the poverty line) as well as insecurity (Tabassum et al., 2017; Onogbosele and Adenuga, 2018; Perpetua et al., 2019; Basar et al., 2019) . Nigeria has a relatively consistent population growth at about $2.5 \%$ (Etchie et al., 2018; Ogunleye et al., 2018), and this huge population provides both advantages and challenges.

Despite all these challenges, Nigerians are undeterred and would rather go and surmount challenges abroad than endure the challenges in their home country. This is a worrisome situation that calls for attention. From the foregoing, this study seeks to examine the impact of push factors on Nigeria's migration rate to propose appropriate measures to reduce migration from Nigeria, foster a friendlier environment for citizens and improve human capital development. While there are micro issues at the individual level, this research explores macro-economic variables and how they impact youth human capital flight. Although some studies have examined this issue from a review standpoint (Ndulu, 2004; Dodani and LaPorte, 2005; Komolafe, 2008; Shafique, 2017; Okunade, 2019; Perpetua et al., 2019), some researchers have carried out similar studies across countries using panel analysis (Shuaibu and Oladayo, 2016). However, economic and socio-political differences across countries may cause data composition to differ. Proposing a common measure for all countries may, therefore, be unrealistic for the countries.

Similar studies to ours that are country-specific include Agbola and Acupan (2010) and Darkwah and Verter (2014). The study by Agbola and Acupan (2010) focused on the Philippines; however, Nigeria has a larger population than the Philippines. On the other hand, Darkwah and Verter (2014) adopted ordinary least squares use in their analysis (with focus on 1991-2011). Also, they ignored the inclusion of human development indices such as infant mortality and life expectancy, which are critical human development factors in Nigeria. Again, their study attempted to include a pull factor (remittances from abroad) in their model; however, many other pull factors and lumping up push and pull factors in the same model may not give the proper picture of the impact of each factor on migration. Again, migration out of Nigeria has continued to grow, and it is important to capture the effects of migration determinants in recent years. 
Our recent study focuses on the push-pull migration theory's push aspect as determinants of net migration in Nigeria between 1990 and 2019. Nigeria's choice is justified based on Nigeria being the country with the largest population in Africa and with the highest level of emigration over the years (Migration Policy Institute (MPI), 2020). Again, it has been observed that for a long time now, the number of emigrants has increased more than immigrants into Nigeria such that the country has continued to record a negative net migration rate as a result of this trend (Orji and Agu, 2018). The rest of this paper follows thus: Section 2 dwells on the literature review; Section 3 provides the methodology adopted; Section 4 presents the empirical analysis. Section 5 presents the conclusion and recommendations from the study.

\section{Literature review}

\subsection{The concept of human capital and human capital flight}

Human capital is described as the total stock of knowledge, skills, competencies and innovative capabilities possessed by a country (Robinson and Florence, 2016). Shuaibu and Oladayo (2016) consider this approach when they affirm in their study that human capital flight has its origin from the increasing pace in the division of human labor. Shuaibu and Oludayo (2016) also follow this trail when they defined human capital as knowledge, competency, attitude and behavior possessed by an individual and further explained that a fundamental source of productivity in the world is its human capital. Fundamentally, human capital is acquired partly through education (Shahbaz et al., 2019), and it is that intangible factor that brings human intelligence, skills, abilities and competencies in the production process and allows for the provision of goods and services (Amadi and Alolote, 2019). Therefore, human capital development concerns all kinds of labor, mentoring, practices, internship and investment, such as efficient medical facilities on managing the available human capital. Human capital can also be improved through effective health-care services, as acknowledged by Oster et al. (2013).

For a third-world country like Nigeria to transcend to a developed nation by tackling poverty and unemployment's persistent issue, a key consideration to the level of human capital development is pertinent. Amadi and Alolote (2019) offer an understanding of human capital development as the process of increasing human capacity to attain higher levels by learning vocational and technical skills to initiate and develop resourcefulness in the individuals in such a methodological way, maintained and deliberate. Human capital development should be methodological, seeing it has defined goals in the form of a learning curriculum followed by series of activities that support knowledge transfer; maintained to sustain its massive impact on the organization or society; and deliberate to ensure welldefined goals accomplishment. Also, human capital education in Nigeria should contain those activities that are well structured, coordinated and implemented to prepare the youths' responsibly to increase the youths' economic participation in every community.

To Kulo et al. (2015), human capital development is an instructional program that is not only technological but business-oriented. They buttressed that human capital education provides students with information and competencies to manage these businesses and further render services to business organizations. Thus, human capital development is referred to as that aspect of education that serves as an enabling agent to students to achieve competence and direct a positive approach toward their work. Enyekit et al. (2011) itemize the objectives of developmental training to include providing learning facilities, detailed outlines that incorporate the instructions of artisans, technicians and other entrepreneurial and self-reliant skilled personnel to form human capital. Abla (2017) recognizes that human capital development, when followed in organizations, can in the interim, influence the poor 


\section{JHASS 4,1}

levels of turnover, working hours spent in improving one's self through personal study adversely affecting performance, not forgetting the issues of matching individual's education program to their roles.

Okoro et al. (2014) tilting these issues clarify that education in developing and underdeveloped countries may negatively affect economic growth if these educated individuals leave their country at the end due to the reasons of the unstable academic calendar, poor remuneration and motivational facilities, political and economic instability, lack of infrastructures (internet and quality study centers) and job dissatisfaction. People need to look for better employment conditions and, as such, migrate to other countries that are better exposed to opportunities that enhance welfare conditions for them and their families (Ghadir, 2019).

Furthermore, Kubalu et al. (2017) evaluation showed the long existing relationship between human development and Nigeria's economic growth. They further identified, with indexes, that education and health are valuable in measuring human capital development and can have a short- or long-term negative impact on the economy, bearing in mind the pull factors (increased wages, improved working conditions, quality of life, intellectual freedom, adequate research facilities), push factors (reduced income earnings, underemployment, inadequate research facilities, political disturbance, failed leaders, dictatorship, poor working conditions, poverty, corrupt practices in appointments and tribal discriminations) and facilitation factors (globalization, efficient communication network, international community of professionals, availability and accessibility of employment information) and easy access to cheap communications (Organisation of Islamic Cooperation (OIC), 2014).

Danquah and Ouattara (2014) consider the undeniable contribution of human capital to both personal and environmental growth as Sub-Saharan African countries join in moving toward the world technology frontier. Alessandra et al. (2017) observe that the moving of experts has been known to positively influence innovation's growth rate by creating a new thinking ability in the receiving destination. Following the endogenous growth theory that establishes the growth of an economy with a positive increase in productivity, which stems from the introduction of new know-how, technologies, expertise and innovations through improved human capital concentration, Nathan (2013) also regards skilled migrants as the core of entrepreneurs, financiers and employees in host regions, who are highly influential in the process of producing as well as consuming those goods and services.

The human capital flight, on the other hand, has a broader definition. It is the migration of skilled people from less developed and/or developing countries to developed ones. Okoro et al. (2014) conclude that brain drain (human capital flight) has been a major constituent in the declining rate of the available human capital present in the economy and, in so doing, has adversely affected the per capita income growth of any country in such situation. Within the health sector, brain drain means the migration of medical science students and health personnel to different regions of the world in search of better education, living standard, quality of life, increased salaries, technological advancement and stability of political conditions (Jenkins et al., 2010; Awire and Okumagba, 2020). Obidike et al. (2015) provided another view to human capital flight when they linked it to the transfer of a country's assets to a foreign country with such purposes as accessing control of one's financial wealth through activities approved by one's own government.

\subsection{Factors leading to human capital flight}

Understanding the reasons behind individuals' decision to relocate to other areas of the world is important in understanding human capital flight determinants. The unavailability of capital investments and infrastructure in one country with the excess or adequate 
presence of those infrastructures in another country is a scenario that encourages human capital flight as the destination country provides opportunities that cut through their social and economic activities, which ultimately breeds societal development, hence contributing Human capital flight greatly to the standard of living obtained (Shuaibu and Oladayo, 2016). Sapkota (2014) critically assesses different infrastructure such as electricity, drinkable water and quality roads on human development index (HDI) using three-component indices of training, wellbeing and earnings the data obtained from 1995-2010, covering 91 developing countries. From these, it was observed that in achieving the sustainable development goals (SDGs), efforts must first be channeled toward annihilating the infrastructural challenges. Therefore, infrastructure is relevant to the process of human development. In another research thought, Chaudhry (2016) in his study established that the issues of favoritism, lack of growth opportunities, job discrimination, professional segregation and dissatisfaction of employees with unfit roles are considered some of the main facilitators to the increasing departure of workers from their home country for "greener pastures."

Oriakhi and Ameh (2014) assessed the influence of government expenditure on the education sector in Nigeria between 1980 and 2011, which proves statistically that education has received lesser attention (proven by decreasing statistics) from the government compared to other countries that invested tremendously in it. Bouhari and Soussi (2017) further buttressed this in their studies by calling for an urgent need for educational subsidies necessary for educational sector advancement. Indeed, investment drives education. If satisfactory and sustainable resources are invested in developing, and underdeveloped countries' current educational sectors, the resultant effect in human capital and economic development will yield positive results (Aransi, 2019).

Nigeria is without doubt lagging when its HDI figure is used in judging the significant improvement on its human capital base instead of achieving the millennium development goals (MDGs) while ultimately trying to fit its plans to incorporate the United Nations larger SDGs. Nigeria has a low human development value of 0.534 as of 2018. Although this index has increased from 0.457 to 0.534 between 2005 and 2018, it is still a low figure, leaving the country at the position of 158 out of the 189 countries and territories in the world (UNDP 2019); an abysmal figure when compared with countries within the first to the 50th position. In part, this situation is due to the challenges present in its governance level, economic and political instability, stewardship responsibility, underutilized mass natural resources and a dearth of labor employed in the country (Federal Government of Nigeria, 2010).

$\mathrm{HDI}$ can also measure long-term progress via life expectancy, knowledge gain, income and standard of life present in those areas (Ita, 2020). By knowledge gain, we mean the obtainable years of schooling for ages 25 and older, access to classroom facilities and the number of children eligible to start school and those who finally do. When addressing living standards in an economy, we consider the gross national income (GNI) per capita (UNDP 2019). At birth, Nigeria's life expectancy is presently 8.4 years, while its mean for the obtainable years of schooling is represented by 1.2 years with a GNI per capita of 57.9\% between 1990 and 2018. These have all attributed to the coefficient of $34.5 \%$ for human inequality (UNDP 2019). Ogundipe (2017) rightly stated that with Nigeria's current average life expectancy (54.3years in 2018 (UNDP, Human Development Report, 2019)), it is disadvantaged not just to the statistics of developed countries but also against many poorer African countries. He identified the causal factors of this life expectancy to malnutrition, high maternal and infant mortality.

Regardless of Nigerian policymakers' commitment so far to seek solutions that can increase our present HDI, much is yet to be achieved. As such, the performance metrics of the HDI continue to suffer a downward trend. Looking at the HDI effect on Nigerians' population, we realize that poverty, destitution, inaccessible education in both the rural and 
JHASS 4,1

urban areas, high school dropout rate and marginalization are core (Robinson et al., 2016). The total number of Nigerians estimated to be officially unemployed as of 2018 was 20.9 million (19\% increase) against 17.6 million in 2017. We still have not done better. The majority of those captured as unemployed are youths within the age brackets of 15-24 and 25-44 years (National Bureau of Statistics, 2018.). To create the expected outcome needed in the country, there is an urgent need to consider the risks of quality education, unemployment, productivity, underpayments and technological innovations absence (Simkovic, 2013). Darkwah and Verter (2014) also affirmed that the unemployment rate and increased population growth increased the migration rate out of Nigeria.

Poor educational standards have led many young people to search for educational opportunities outside Nigeria. Komolafe (2008) asserted that many young people migrate to Canada because of the advancement in post-secondary education, providing economic and social empowerment opportunities. Furthermore, Okafor and Chimereze (2020) opined that limited educational opportunities, among other factors, contributed to the push factors that influence nurses' migration from Nigeria. Little advancement in technology in the health sector, insufficient study leave period and epileptic education system all contribute to medical practitioners' migration. Therefore, migrants are more encouraged to migrate to countries where their lifestyle will improve.

Ita (2020) also asserted that although life expectancy has improved in Nigeria over the years, this increase is not commensurate compared to other developing countries. There is, therefore, the need to improve the well-being of Nigerians, as this will further increase their life expectancy. Corroborating this assertion, Shabhaz et al. (2019) emphasized the importance of human capital development in host countries as a factor influencing migration. Improved human capital in home countries, thus, tends to reduce migration.

From another angle, the material comfort of their peers in advanced countries influences young people's desire to migrate. Aside from the aforementioned economic factors, migrants believe that there is a better life outside the country, and seeing foreigners sometimes creates a picture of affluence among their peers living outside the country. As a result of this, many people give up their jobs in the home country to enjoy the "greener pasture" at the other end of the divide (Okunade, 2019).

\subsection{Theoretical review}

2.3.1 Push-pull models. The push-pull models were first discussed in the $19^{\text {th }}$ century by Ravenstein in England. It is an amalgamation of factors that entice youth to leave their home country and factors that fascinate them to move to the destination country (Harris and Todaro, 1970; Ortega and Peri, 2009; Van Hear Bakewell and Long, 2017). Factors that discourage citizens in the home country are known as "push factors," while the factors that entice them to the destination countries are called the "pull factors." While the economic, social and political factors are similar in both home and destination countries, however, these factors are favorable in destination countries and unfavorable in the home country (Stanojoska and Petrevski, 2012). From another perspective, the factors motivating migration have been discussed by Mohamed and Abdul-Talib (2020) as factors that push or pull migrants back to the home country. This was discussed under three major headings: economic, psychological and situational. Some of the economic factors are lack of employment opportunities and difficulty using skills possessed in the home country. The psychological push -factors identified by Mohamed and Abdul-Talib (2020) are family reunion and altruism. Lastly, situational push factors are identified from the perspective of the host country. They are discrimination in the host country, inability to fit into the host country and difficulties associated with belonging to the minority group. Therefore, we see 
that the propositions of Mohamed and Abdul-Talib (2020) are quite contrary to those of Harris and Todaro (1970). Mohamed and Abdul-Talib (2020) further opined that pull factors such as untapped investment opportunities and increased demand (economical pull factors), seeking for identity, old age (psychological pull factors) and political development (situational pull factors) impact migrants' decisions in host countries.

Although Stanojoska and Petrevski (2012) also classified the drivers of migration to be economical, social, cultural and political, however, their discussions are done in line with those of Harris and Todaro (1970). Lower population density, environmental factors, economic conditions Human capital flight (higher wages) in developed and industrialized countries, etc. have "pulled" many youths to advanced countries away from the unfavorable economic and environmental conditions experienced in the home country. As a result of the rise in globalization and advancement in technology, many people from developing countries interact with people in advanced countries, which creates a desire to experience the high standards of living enjoyed in developed nations (Fergus, 2005; Stanojoska and Petrevski, 2012). Although developing nations have been fraught with low standards of living and poor human development for many years, the continued interaction with people in advanced countries makes the conditions in the developing countries more unbearable for its aspiring citizens. Increased unemployment rates and citizens' inability to obtain good-paying jobs that will lift them out of poverty are other factors that influence migrants' decisions (Simkovic, 2013; Stanojoska and Petrevski, 2012). With the inability to continue coping with the harsh realities around them, people from developing countries find a way of migrating into the developed countries where there are economic and socio-political opportunities. Despite the continued relevance of the theory in the study of migration, it has been criticized based on its post hoc character (O'Reilly, 2013), tendency to single out unlikely direct "causes" of migration (environment, population growth) (Jung et al., 2017) and ruling out of agency and preferences (migrants as passive pawns) (Boucher and Gest, 2015). Again, some critics have seen the theory as being "simplistic" (de Haas, 2011); however, the theory is still relevant in that the structural factors identified by the theory to a large extent influence migration practice (Van Hear et al., 2017). For this current study, we adopt the push-pull theory, with a specific focus on the push factors in the Nigerian economy.

\section{Methodology}

\subsection{Model description}

The model in this study hinges on the push factor side of the push-pull theory of Ravenstein. It is necessary to focus on the push factors because the study is a country-specific study, with special attention to factors that trigger migration out of Nigeria. Push factors that have been identified from the literature include increased unemployment, mortality rate, population density, poor educational facilities, among others (Dodani and LaPorte, 2005; Mohamed and Abdul-Talib, 2020; Okoro et al., 2014; Shafique, 2017). However, due to data paucity, our study adopts push factors such as infant mortality rate, life expectancy, population growth rate and unemployment rate obtained from the United Nation's World Population Prospects between 1990 and 2019, as displayed in Table 1.

From the foregoing, we thus formulate a simple model as follows:

$$
N M R=f(L E, I M, P G R, \text { UNEMPR })
$$

where:

$$
\begin{aligned}
N M R & =\text { net migration rate; } \\
L E & =\text { life expectancy; } \\
I M R & =\text { infant mortality rate; }
\end{aligned}
$$




\begin{tabular}{|c|c|c|c|c|c|c|}
\hline \multirow{5}{*}{$\begin{array}{l}\text { JHASS } \\
4,1\end{array}$} & Year & NMR & LE & UNEMPR & IMR & PGR \\
\hline & 1990 & -1.49 & 45.92 & 3.562 & 125.874 & 2.61 \\
\hline & 1991 & -2.01 & 45.90 & $\begin{array}{l}3.0062 \\
3.562\end{array}$ & 125.87 & 2.58 \\
\hline & 1992 & -1.54 & 45.89 & 3.562 & 125.865 & 2.55 \\
\hline & 1993 & -1.56 & 45.87 & 3.826 & 125.861 & 2.53 \\
\hline \multirow{26}{*}{10} & 1994 & -2.65 & 45.90 & 4.016 & 124.389 & 2.52 \\
\hline & 1995 & -2.72 & 45.92 & 3.947 & 122.918 & 2.52 \\
\hline & 1996 & -2.23 & 45.95 & 3.951 & 121.446 & 2.52 \\
\hline & 1997 & -2.86 & 45.97 & 3.974 & 119.975 & 2.52 \\
\hline & 1998 & -2.94 & 46.00 & 3.992 & 118.503 & 2.52 \\
\hline & 1999 & 11.52 & 46.19 & 4.009 & 115.594 & 2.53 \\
\hline & 2000 & 10.33 & 46.38 & 3.954 & 112.684 & 2.54 \\
\hline & 2001 & 9.36 & 46.56 & 4.029 & 109.775 & 2.54 \\
\hline & 2002 & 8.56 & 46.75 & 4.11 & 106.865 & 2.55 \\
\hline & 2003 & 7.88 & 46.94 & 4.063 & 103.956 & 2.57 \\
\hline & 2004 & 11.15 & 47.50 & 3.98 & 101.031 & 2.59 \\
\hline & 2005 & 10.03 & 48.07 & 3.87 & 98.106 & 2.62 \\
\hline & 2006 & 8.81 & 48.63 & 3.666 & 95.18 & 2.65 \\
\hline & 2007 & 8.38 & 49.20 & 3.439 & 92.255 & 2.67 \\
\hline & 2008 & 7.73 & 49.76 & 3.424 & 89.33 & 2.69 \\
\hline & 2009 & -2.48 & 50.20 & 3.757 & 86.458 & 2.7 \\
\hline & 2010 & -2.54 & 50.64 & 3.77 & 83.587 & 2.71 \\
\hline & 2011 & -2.86 & 51.07 & 3.697 & 80.715 & 2.71 \\
\hline & 2012 & -2.68 & 51.51 & 3.693 & 77.844 & 2.72 \\
\hline & 2013 & -2.75 & 51.95 & 3.703 & 74.972 & 2.71 \\
\hline & 2014 & -2.55 & 52.40 & 4.437 & 72.406 & 2.7 \\
\hline & 2015 & -2.33 & 52.84 & 5.313 & 69.84 & 2.68 \\
\hline & 2016 & -2.68 & 53.29 & 6.237 & 67.274 & 2.66 \\
\hline & 2017 & -2.45 & 53.73 & 6.013 & 64.708 & 2.64 \\
\hline & 2018 & -2.82 & 54.18 & 6.026 & 62.142 & 2.62 \\
\hline & 2019 & -2.26 & 54.49 & 6.11 & 60.662 & 2.6 \\
\hline
\end{tabular}

Table 1.

Source: World Population Prospects (2019).

$P G R=$ population growth rate; and $U N E M P R=$ unemployment rate.

\subsection{Unit root test}

The unit root test is shown in Table 2. It is important to conduct the unit root test to confirm the stationarity of the variables used. The unit result will also give a guide on the right analysis to adopt and the avoidance of spurious regression. The result shows that except for population growth rate (stationary at level $(\mathrm{I}(0))$ ), all the other variables reject the null hypothesis of unit root presence at level and only became stationary at the first difference (I(1))for the two tests adopted: augmented Dickey-Fuller (ADF) and the Phillips-Perron (PP) tests. As the variables are stationary at level and first difference, the auto-regressive distributed lag (ARDL) model, as proposed by Pesaran et al. (2001), will be appropriate for empirical analysis. This technique is also desirable because it has the ability to provide consistent and efficient results, especially when using a small sample size (Pesaran et al., 2001).

\subsection{Empirical model}

The empirical model is estimated as: 


$$
N M R=\beta_{0}+\beta_{1} L E+\beta_{2} I M+\beta_{3} P G R+\beta_{4} U N E M P R+\mu
$$

where $\beta_{0}, \beta_{1}-\beta_{4}, \mu$ are the intercept, coefficients and error term, respectively.

The ARDL form of the model is as follows:

$$
\begin{aligned}
N M R_{t}= & \beta_{0}+\beta_{1} N M R_{t-1}+\beta_{2} L E_{t-1}+\beta_{3} I M_{t-1}+\beta_{4} P G R_{t-1}+\beta_{5} \text { UNEMP }_{t-1} \\
& +\sum_{i=1}^{m} a_{1} \Delta N M R_{t-1}+\sum_{i=1}^{m} a_{2} \Delta L E_{t-1}+\sum_{i=1}^{m} a_{3} \Delta \log I M_{t-1} \\
& +\sum_{i=1}^{m} a_{4} \Delta P G R_{t-1}+\sum_{i=1}^{m} a_{5} \Delta U N E M P_{t-1}+\mu_{t}
\end{aligned}
$$

where

$\Delta$ is the difference operator; and

$a_{1}, \ldots, a_{5}$ are the short-run dynamics of the independent variables.

Following Pesaran et al. (2001), the null hypothesis of no long-run relationship ( $\mathrm{HO}: \beta_{1}=$ $\beta_{2}=\beta_{3}=\beta_{4}=\beta_{5}=0$ ) is examined. The empirical error-correction model (ECM) is stated as:

$$
\begin{aligned}
N M R_{t} & =\beta_{0}{ }_{m} \\
& +\sum_{i=1}^{m} a_{1} \Delta N M R_{t-1}+\sum_{i=1}^{m} a_{2} \Delta L E_{t-1}+\sum_{i=1}^{m} a_{3} \Delta \log I M_{t-1} \\
& +\sum_{i=1}^{m} a_{4} \Delta P G R_{t-1}+\sum_{i=1}^{m} a_{5} \Delta \text { UNEMP }_{t-1}+\lambda_{1} E C M_{t-1}+\mu_{t}
\end{aligned}
$$

where the $E C M_{t-1}$ is expected to be negative and shows the speed of adjustment of the net migration rate to equilibrium in the long run after a disequilibrium occurs due to change in the explanatory variables

\section{Empirical result presentation and discussions}

The descriptive statistics of the data used are displayed in Table 3. The average net migration rate, life expectancy, infant mortality rate, population growth rate and unemployment rate for the period are $2 \%$, 49 years, 98 per 1,000 live births, $3 \%$, and $4 \%$,

\begin{tabular}{lcccccc}
\hline Variable & $\begin{array}{c}\text { ADF critical } \\
\text { value }\end{array}$ & $\begin{array}{c}T \text {-statistics (5\% } \\
\text { significance level) }\end{array}$ & $\begin{array}{c}\text { Order of } \\
\text { integration }\end{array}$ & $\begin{array}{c}\text { PP critical } \\
\text { value }\end{array}$ & $\begin{array}{c}\text { T-statistics (5\% } \\
\text { significance level) }\end{array}$ & $\begin{array}{c}\text { Order of } \\
\text { integration }\end{array}$ \\
\hline NMR & -5.3055 & -2.9712 & $\mathrm{I}(1)$ & -5.3334 & -2.9719 & $\mathrm{I}(1)$ \\
PGR & -3.651 & -2.9763 & $\mathrm{I}(0)$ & -3.1313 & -2.9678 & $\mathrm{I}(0)$ \\
logIM & -4.0397 & -2.9719 & $\mathrm{I}(1)$ & -8.5293 & -2.9719 & $\mathrm{I}(1)$ \\
logLE & -7.25 & -2.9719 & $\mathrm{I}(1)$ & -11.7829 & -2.9719 & $\mathrm{I}(1)$ \\
UNEMPR & -2.8614 & -1.9534 & $\mathrm{I}(1)$ & -2.9506 & -2.9719 & $\mathrm{I}(1)$
\end{tabular}

Source: Authors' computation

Table 2. $\mathrm{ADF}$ and $\mathrm{PP}$ unit root tests 
$\underset{4,1}{\text { JHASS }}$

respectively. The maximum rate of migration was $12 \%$, with the lowest at $-3 \%$. The highest life expectancy is 54, and this was as of 2019, this is about $40 \%$ lower than the life expectancy in Algeria, with about 76 years life expectancy (Sen Nag, 2017). Although the population growth rate has also increased from 2.52 to $2.72 \%$ over the years, the increase is not as rapid as that of the unemployment rate that stood at 6\% in 2019 compared to about $3 \%$ in the 1990s. The Jacque-Bera results show that most of the variables are normally distributed.

\subsection{Autoregressive distributed lag model estimates}

The long-run ARDL estimates are presented in Table 4. The estimates of the net migration rate results in past periods had a significant positive impact on the current period. This implies that a percent increase in migration will further increase migration by $40 \%$. The infant mortality rate shows a high negative relationship with the net migration rate; life expectancy years are also significantly negative in both first and second lags. This implies an increase in the infant mortality rate actually reduced the net migration rate by a substantial amount (over $400 \%$ ).

On the other hand, the negative relationship between life expectancy and migration rate implies an increase in life expectancy in the first and second lags reduced the migration rate. This shows that improvement in life expectancy is a stimulating factor in reducing migration. Okafor and Chimereze (2020) indeed complemented this assertion by explaining that migrants sometimes leave their home country to enjoy enhanced life expectancy host countries offer. Therefore, if migrants can enjoy a longer and better life in their home country, the likelihood of migrating will reduce. Our findings also supported the submission of Ita (2020) and Shabhaz et al. (2019). These studies asserted that human capital development through increased life expectancy would enhance the economy's socioeconomic development. This will ultimately reduce migration.

The population growth rate was positive in the current period but positive and significant in the second lag. An increase in population growth rate increased the migration rate by over $181 \%$. This proves that an increase in population growth rate is a driving force to the net migration rate experienced in the economy. Ita (2020) also rightly asserted that an increase in population growth rate in Nigeria is a key determining factor for human capital development. An increase in population in the face of limited infrastructural development

\begin{tabular}{lccccc}
\hline & NMR & LE & IM & PGR & UNEMPR \\
\hline Mean & 1.511667 & 48.85333 & 97.8695 & 2.609 & 4.189733 \\
Median & -2.245 & 47.785 & 99.5685 & 2.605 & 3.9525 \\
Maximum & 11.52 & 54.49 & 125.874 & 2.72 & 6.237 \\
Minimum & -2.94 & 45.87 & 60.662 & 2.52 & 3.424 \\
Standard deviation & 5.715511 & 3.027812 & 22.38845 & 0.072319 & 0.835439 \\
Skewness & 0.749028 & 0.528354 & -0.202258 & 0.152634 & 1.618559 \\
Kurtosis & 1.656413 & 1.771405 & 1.633703 & 1.510609 & 4.149821 \\
Jacque-Bera & 5.061749 & 3.282596 & 2.537999 & 2.889344 & 14.75128 \\
Probability & 0.079589 & 0.193728 & 0.281113 & 0.235823 & 0.000626 \\
Sum & 45.35 & $1,465.6$ & $2,936.085$ & 78.27 & 125.692 \\
Sum sq. dev & 947.3448 & 265.8617 & $1,4536.04$ & 0.15167 & 20.24078 \\
Observations & 30 & 30 & 30 & 30 & 30
\end{tabular}

Table 3.

Source: Authors' computation (Eviews Version 11) 
ultimately impacts the welfare of the populace, and this contributes to the push factors of migrants from Nigeria.

Interestingly, our results show a negative relationship between infant mortality and migration rate. An increase in infant mortality rate reduced migration, implying that newborns' deaths do not act as a push factor of migration. This is contrary to Ita's (2020) assertion that an increase in infant mortality (as a human capital development challenge) negatively influences migration. Finally, the impact of the unemployment rate on the model is positive; however, not significant. The findings of Darkwah and Verter (2014) also flight complement our findings. Darkwah and Verter (2014) observed a positive relationship between unemployment and the number of emigrants from Nigeria.

The $R^{2}$ measures the goodness of fit and shows $88 \%$ of the variation in net migration from Nigeria. The $F$-statistic is statistically significant and proves that all the dependent variables are jointly significant in explaining variations in the dependent variable. At the same time, the Durbin-Watson test shows that the model does not suffer from autocorrelation.

As presented in Table 5 , the bounds test shows a cointegrating relationship between the variables. The $F$-statistics is greater than the lower and upper bound at all the significance tested level, which shows that all the variables are cointegrated for long-run relationships.

As revealed in Table 6, the ECM carries a negative sign as expected and shows that the speed of adjustment to equilibrium (disequilibrium occurs due to changes in the explanatory variables) is about $60 \%$. Life expectancy negatively affects the migration rate in the short run but insignificantly. However, in the first and second, the positive impact is seen on the net migration rate; thus, a higher life expectancy rate in the first and second lags significantly increased net migration contrary to the long-run estimates. The population growth rate only significantly impacted the net migration rate at a $1 \%$ level of significance

\begin{tabular}{|c|c|c|c|c|}
\hline Variable & Coefficient & Standard error & $T$-statistic & Probability* \\
\hline $\operatorname{NMR}(-1)$ & 0.396488 & 0.187354 & 2.116255 & 0.0504 \\
\hline LOGIM & -314.7153 & 84.33904 & -3.73155 & 0.0018 \\
\hline LOGLE & -46.16322 & 217.2996 & -0.21244 & 0.8344 \\
\hline LOGLE $(-1)$ & -571.8769 & 215.5066 & -2.65364 & 0.0173 \\
\hline LOGLE(-2) & -472.5702 & 207.743 & -2.274782 & 0.037 \\
\hline LOGLE(-3) & -351.4017 & 211.0457 & -1.66505 & 0.1154 \\
\hline PGR & 78.86322 & 89.0233 & 0.885872 & 0.3888 \\
\hline PGR(-1) & -231.109 & 154.979 & -1.491227 & 0.1554 \\
\hline PGR(-2) & 181.0802 & 95.36627 & 1.898786 & 0.0758 \\
\hline UNEMPR & 0.406509 & 2.259756 & 0.179891 & 0.8595 \\
\hline $\mathrm{C}$ & 2973.247 & 772.9377 & 3.846684 & 0.0014 \\
\hline$R^{2}$ & 0.882664 & \multicolumn{2}{|c|}{ Mean dependent variable } & 1.866296 \\
\hline Adjusted $R^{2}$ & 0.809329 & \multicolumn{2}{|c|}{ SD dependent variable } & 5.926552 \\
\hline $\mathrm{SE}$ of regression & 2.587884 & \multicolumn{2}{|c|}{ Akaike information criterion } & 5.031125 \\
\hline Sum squared residual & 107.1543 & \multicolumn{2}{|c|}{ Schwarz criterion } & 5.559058 \\
\hline Log likelihood & -56.92018 & \multicolumn{2}{|c|}{ Hannan-Quinn criterion } & 5.188107 \\
\hline$F$-statistic & 12.03603 & \multirow{2}{*}{\multicolumn{2}{|c|}{ Durbin-Watson statistic }} & 2.486614 \\
\hline $\operatorname{Prob}(F$-statistic $)$ & 0.000011 & & & \\
\hline
\end{tabular}

Source: Authors' estimation (Eviews Version 11)

Table 4. Long-run ARDL estimates 
JHASS

4,1

14

in the first lag, while it positively but insignificantly impacted the current period's net migration rate.

\subsection{Diagnostic tests}

As shown in Table 7, the diagnostic tests reveal that the model was well specified and did not suffer from heteroscedasticity and serial correlation. The Jacque-Bera test shows that the model variables are not normally distributed, and this could have been impacted by fluctuations in the unemployment rate over the period. The Cusum and Cusum square tests displayed in Figures 1 and 2 show that the model used in the analysis is stable. From the foregoing, therefore, the results from the study are reliable to a large extent.

\begin{tabular}{lcccc}
\hline F-bounds test & \multicolumn{4}{c}{ Null hypothesis: no levels relationship } \\
\hline Test statistic & Value & Significance & $\mathrm{I}(0)$ & $\mathrm{I}(1)$ \\
$F$-statistic & 4.393582 & $10 \%$ & 2.2 & 3.09 \\
K & 4 & $5 \%$ & 2.56 & 3.49 \\
& & $2.50 \%$ & 2.88 & 3.87 \\
& $1 \%$ & 3.29 & 4.37 \\
\multicolumn{2}{l}{ Source: Authors' estimation (Eviews Version 11) } & & & \\
\hline
\end{tabular}

ECM estimates $\quad$ Source: Authors' estimation (Eviews Version 11)

\begin{tabular}{lcccc}
\hline Variable & Coefficient & Std. error & t-statistic & Prob \\
\hline D(LOGLE) & -46.16322 & 92.1114 & -0.501167 & 0.6231 \\
D(LOGLE(-1)) & 823.9718 & 187.4004 & 4.396852 & 0.0005 \\
D(LOGLE(-2)) & 351.4017 & 113.9649 & 3.083421 & 0.0071 \\
D(PGR) & 78.86322 & 59.6138 & 1.322902 & 0.2045 \\
D(PGR(-1)) & -181.0802 & 59.5569 & -3.040457 & 0.0078 \\
CointEq(-1)* & -0.603512 & 0.102601 & -5.882131 & 0
\end{tabular}

Table 5.

Long-run form and bounds test
Jacque-Bera

10.22863

(0.00601)

Ramsey

Heteroscedascity

Serial correlation

Table 7.

Diagnostic tests
Source: Authors' estimation (Eviews Version 11)
1.029384

(0.3196)

1.195633

(0.3618)

1.587906

(0.239) 


\section{Summary, conclusion and recommendations}

The findings from the study show that the past's net migration rate has positively impacted the current net migration rate in the economy. This shows that the continued migration of citizens out of Nigeria triggers higher migration. This is not surprising, as youths and older adults alike believe migrants enjoy better lives in host countries and wish to enjoy such a better lifestyle. Another human capital development index used is the life expectancy in years. Life expectancy has negatively impacted the net migration rate; the higher the life expectancy rate, the lower the migration rate and vice versa. This proves that providing a sustainable economy that improves life expectancy will also reduce human capital flight. Population growth rates also positively impacted the net migration rate. The higher the population growth rate, the higher the net migration rate. However, the unemployment rate shows a positive but insignificant relationship with human capital flight in our study. Our findings show that most of the push factors discussed in the literature contribute to the net migration rate. The study, however, found that increase in infant mortality does not directly impact migration from Nigeria. Increased infant mortality implies reduced population growth, and this may have accounted for the reduction in migration.

From the findings of this study, it is important to improve citizens' life expectancy by providing major drivers such as quality health-care service, education, nutrition and accessible infrastructure. This will improve their quality of life. A polluted environment, poor health delivery and poor education reduce an average human being's lifespan, and these should be eliminated from the economy. With a better lifestyle, the migration rate will

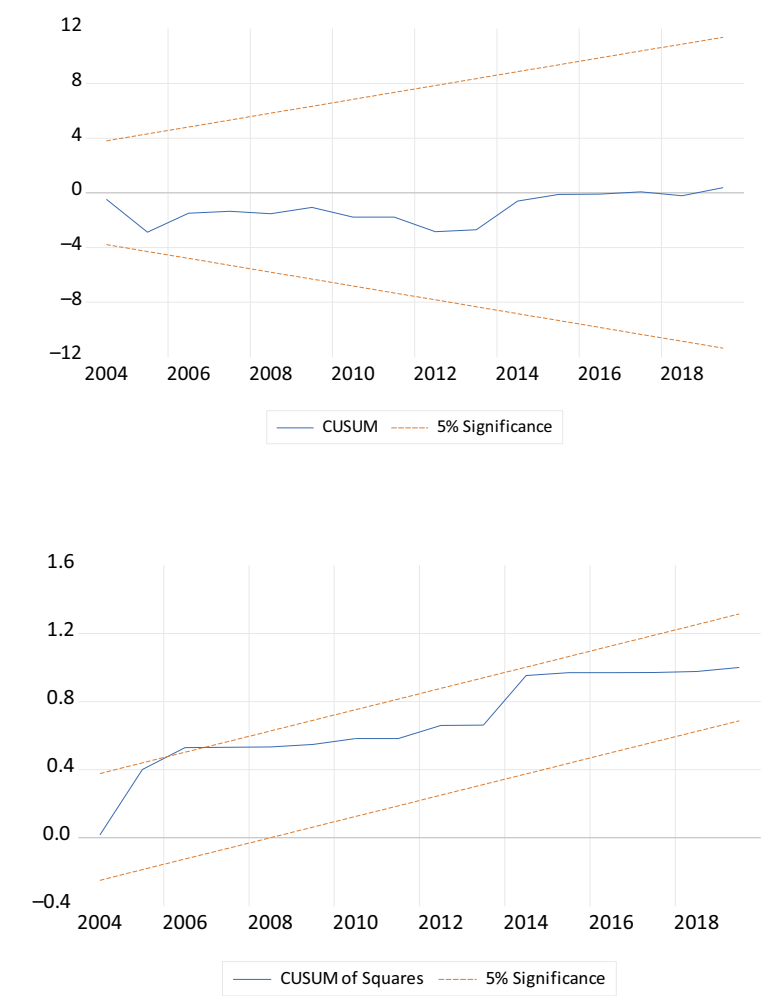

Figure 1. Cusum test

Figure 2. Cusum squares test 


\section{JHASS 4,1}

reduce, and Nigerians will be more productive in their home country. Again, it is important to put in place fiscal and monetary policies that will enhance decent job creation, ultimately reducing unemployment. Moreover, the rising trend in population needs to be checked, as this has been seen to be a contributing factor to human capital flight from both current and previous studies. There should be sustained advocacy in collaboration with key stakeholders for family planning and population control to manage the population growth rates. Also, the reduced population will enable people to have access to adequate infrastructural development, which would not have been sufficient for a larger population. Lastly, the continued rise in net migration over the years may be triggered by the unbalanced information shared by other migrants to advanced countries. Thus, many people in home countries opine that relocation automatically takes them to Eldorado and wants to transition overseas, even if it is through illegal means. Again, many special migrant schemes are being floated by developed countries to attract the best and the brightest from developing countries; this needs to be curtailed to avoid a further capital flight from the country. While many studies have examined the push-pull factors of migration theoretically, our study provides an empirical analysis of the push factors of migration from Nigeria. The study also found the push-pull theory relevant to a large extent in Nigeria.

\section{Limitations and suggestion for further studies}

Due to the paucity of data, the study was restricted to using the available variables and up to date. However, an area that was not considered in our current study is the political dimension as a push factor to migration. Future studies can incorporate this in their model and examine the effect on migration, especially in other African countries struggling with human capital flight. Again, some other indicators that are country relevant can be examined in further studies. Future studies can comparatively analyze the impact of pull factors of migration from more developed African countries to advanced countries. These will enlarge the frontier of knowledge and enrich the literature on the empirical analysis of human capital flight determinants.

\section{References}

Abla, A. (2017), "Human Capital investment and economic growth in Saudi Arabia: error correction model", International Journal of Economics and Financial Issues, Vol. 7 No. 4, pp. 104-112.

Agbola, F. and Acupan, A. (2010), "An empirical analysis of intentional labor migration in the Philippines", Economic Systems, Vol. 34 No. 4, pp. 386-396.

Akanle, O., Fayehun, O., Adejare, G. and Orobome, O. (2019), "International migration, kinship networks, and social capital in South-Western Nigeria”, Journal of Borderlands Studies, Vol. 1, pp. 1-14.

Alessandra, F., Isha, R. and Kathryn, R. (2017), "The interregional migration of human capital and its regional consequences: a review”, Regional Studies, doi: 10.1080/00343404.2016.1263388.

Amadi, K. and Alolote, I. (2019), "Human capital investment as a catalyst for sustainable economic development in Nigeria", International Journal of Management Science and Business Administration, Vol. 5 No. 5, pp. 13-22.

Amrevurayire, E. and Ojeh, V. (2016), "Consequences of Rural-Urban migration on the source region of Ughievwen Clan, Delta state Nigeria”, European Journal of Geography, Vol. 7 No. 3, pp. $42-57$.

Aransi, W. (2019), "Direction of causality between human capital investment and economic growth in Nigeria: lesson for policy makers", International Journal of Academic Management Science Research (IJAMSR), Vol. 3 No. 2, pp. 19-26. 
Awire, E. and Okumagba, M. (2020), "Medical education in Nigeria and migration: a mixed-methods study of how the perception of quality influences migration decision making", available at: https://doi.org/10.15694/mep.2020.000001.1 (accessed 30 April 2020).

Basar, U.M., Ab Hamid, R., Asid, W., Sulaiman, E., Bahri, N., Sulaiman, N. and Ramli, (2019), An Analysis of Capital Flight Risk: Case for Human Capital in Inclusive Growth, Emerald Publishing Limited, pp. 31-14, available at: https://doi.org/10.1108/978-1-83867-479-320191003

Boucher, A. and Gest, J. (2015), "Migration studies at a crossroads: a critique of immigration regime typologies”, Migration Studies, Vol. 3 No. 2, pp. 182-198.

Bouhari, M. and Soussi, M. (2017), “About the relationship between education, investment and growth: identification and causality for 5 MENA countries - (Algeria-Egypt-Morocco-Tunisia and Turkey)". Business Economics Journal, Vol. 8 No. 2, pp. 1-13.

Chibuokwu, R.A. and Nwosu, F.I. (2016), “ Education and human capital development in Nigeria: the way forward”, Journal of Resourcefulness and Distinction, Vol. 12 No. 1.

Dako-Gyeke, M. (2016), "Exploring the migration intentions of Ghanaian youth: a qualitative study", Journal of International Migration and Integration, Vol. 17 No. 3, pp. 723-744.

Danquah, M. and Ouattara, B. (2014), "Productivity growth, human capital, and distance to frontier in Sub-Saharan Africa”, Journal of Economic Development, Vol. 39 No. 4, pp. 27-48.

Darkwah, S.A.S. and Verter, N. (2014), "Determinants of international migration: the Nigerian experience", Acta Universitatis Agriculturae Et Silviculturae Mendelianae Brunensis, Vol. 62 No. 2, pp. 321-327.

Darkwah, S.A. and Verter, N. (2014), "Determinants of international migration: the Nigerian experience", Acta Universitatis Agriculturae et Silviculturae Mendelianae Brunensis, Vol. 62 No. 2, pp. 321-327.

de Haas, H. (2011), "The internal dynamics of migration processes: a theoretical inquiry", Journal of Ethnic and Migration Studies, Vol. 36 No. 10, pp. 1587-1617.

Dodani, S. and LaPorte, R. (2005), "Brain drain from developing countries: how can brain drain be converted into wisdom gain?", Journal of the Royal Society of Medicine, Vol. 98 No. 11, pp. 487-491.

Enyekit, E., Amaehule, S. and Teerah, L. (2011), “Achieving human capital development in Nigeria through vocational education for nation-building", paper presented at the 1st international technology, education, and environment Conference, Federal College of Education (I) Qinoku, Rivers State.

Etchie, T., Etchie, A., Adewuyi, G., Pillarisetti, A., Sivanesan, S., Krishnamurthi, K. and Arora, N. (2018), "The gains in life expectancy by ambient PM2. 5 pollution reductions in localities in Nigeria", Environmental Pollution, Vol. 236, pp. 146-157.

Federal Government of Nigeria (2010), "Nigeria vision 20: 2020", The First National Implementation Plan (2010-2013).

Fergus, L. (2005), “Trafficking in women for sexual exploitation. Melbourne”, Australian Centre for the Study of Sexual Assault (Briefing 5).

Ghadir, G. (2019), "The effect of lack of human rights on brain drain and human flight", TURAN Center for Strategic Researches, Vol. 11 No. 42, pp. 1-16.

Harris, J. and Todaro, M. (1970), "Migration, unemployment, and development: a two-sector analysis", The American Economic Review, Vol. 60 No. 1, pp. 126-142.available at: https://doi.org/10.1163/ 9789004357044_014 (accessed 15 April 2020).

Human Development Report (2019), "Beyond income, beyond averages, beyond today: inequalities in human development in the 21st century", Briefing note for countries on the 2019 Human Development Report, available at: http://hdr.undp.org/sites/default/files/hdr_2019_overview__english.pdf (accessed 15 April 2020). 


\section{JHASS 4,1}

Ita, E. (2020), "Human development in Nigeria", International Journal of African and Asian Studies, Vol. 61, pp. 40-49.

Jenkins, R., Kydd, R., Mullen, P., Thomson, K., Sculley, J., Kuper, S., Carroll, J., Gureje, O., Hatcher, S., Brownie, S. and Carroll, C. (2010), "International migration of doctors and its impact on availability of psychiatrists in low and middle-income countries", PLoS One, Vol. 5 No. 2, p. e9049, doi: 10.1371/journal.pone.0009049.

Jung, J., Han, H. and Oh, M. (2017), "Travelers' switching behavior in the airline industry fromthe perspective of the push-pull-mooring framework", Tourism Management, Vol. 59, pp. 139-153.

Komolafe, J. (2002), "Searching for fortune: the geographical process of Nigerian migration to Dublin, Ireland", Journal of African Migration, available at: www.africamigration.com/issue/sep2002/ j_komolafe_searching.pdf (accessed 15 April 2020).

Komolafe, J. (2008), "Nigerian migration to Ireland: movements, motivations, and experiences", Irish Geography, Vol. 41 No. 2, pp. 225-241.doi:, doi: 10.1080/00750770802077016.

Kubalu, A., Mustapha, A. and Suwaid, Z. (2017), "A dynamic analysis of the relationship between human development and economic growth in Nigeria", International Journal of Advanced Studies in Economics and Public Sector Management, Vol. 5 No. 1, pp. 01-21.

Kulo, V., Effah, M. and Okudare, J. (2015), "Funding; an imperative for effective implementation of business education programme in tertiary institutions in Nigeria", Nigerian Journal of Business Education, Vol. 2 No. 3, pp. 55-64.

Lemmermann, D. and Riphahn, R. (2018), "The causal effect of age at migration on youth educational attainment", Economics of Education Review, Vol. 63, pp. 78-99.

Light, I., Bhachu, P. and Karageorgis, S. (2017), "Migration networks and immigrant entrepreneurship", Immigration and Entrepreneurship, Routledge.

Liu, Y., Deng, W. and Song, X. (2018), "Influence factor analysis of migrants' settlement intention: considering the characteristic of city", Applied Geography, Vol. 96, pp. 130-140.]

Migration Policy Institute (MPI) (2020), "Migration information source-Nigeria", available at: www. migrationpolicy.org/country-resource/nigeria (accessed 30 April 2020).

Mohamed, M.A. and Abdul-Talib, A.N. (2020), "Push-pull factors influencing international return migration intentions: a systematic literature review", International Return Migration Intentions, Vol. 14 No. 2, pp. 231-246.

Nathan, M. (2013), "The wider economic impacts of High-Skilled migrants: a survey of the literature", Discussion Paper 7653, Institute for the Study of Labour (IZA) discussion paper series, Bonn, available at: http://ftp.iza.org/dp765

National Bureau of Statistics (2018), "Nigeria data portal, Central bank of Nigeria".

Ndulu, B.J. (2004), "Human capital flight: stratification, globalization, and the challenges to tertiary education in Africa", JHEA/RESA, Vol. 2 No. 1, pp. 57-91.

Obidike, P., Uma, K., Odionye, J. and Ogwuru, O. (2015), "The impact of capital flight on economic development: Nigeria in focus", British Journal of Economics, Management and Trade, Vol. 10 No. 3, pp. 1-13.

Ogunleye, O., Owolabi, O. and Mubarak, M. (2018), "Population growth and economic growth in Nigeria: an appraisal", International Journal of Management, Accounting, and Economics, Vol. 5 No. 5, pp. 282-299.

Okafor, C. and Chimereze, C. (2020), "Brain drain among Nigerian nurses: implications to the migrating nurse and the home country", International Journal of Research and Scientific Innovation, Vol. 7 No. 1, pp. 15-21.

Okoro, C., Omeluzor, S. and Bamidele, A. (2014), "Effect of Brain drain (human capital flight) of librarians on service delivery in some selected Nigerian universities", SAGE Open, Vol. 4 No. 3, doi: 10.1177/2158244014541131. 
Okunade, S. (2019), “Gargantuan out-migration: an emerging culture among youths in Nigeria”, IPPA Public Policy Paper, available at: www.ippapublicpolicy.org/file/paper/5d0a2d20b3a36.pdf (accessed 30 April 2020).

Onogbosele, D. and Adenuga, O. (2018), "Challenges of human capital formation in Nigeria: a descriptive analysis", Lafia Journal of Economics and Management Sciences, Vol. 3 No. 2, pp. 75-101.

O'Reilly, K. (2013), "International migration and social theory", The Encyclopedia of Global Human Migration, doi: 10.1002/9781444351071.wbeghm307.

Organisation of Islamic Cooperation (OIC) (2014), "The Plight of Human capital Flight in OIC Countries". Statistical, Economic and Social Research and Training Centre for Islamic Countries.

Orji, A. and Agu, C. (2018), "Analysis of migration, regional characteristics, and socioeconomic outcomes in developing economies: empirical evidence from Nigeria”, Journal of International Migration and Integration, Vol. 19 No. 3, pp. 565-581.

Oriakhi, D. and Ameh, E. (2014), "Government expenditure and the development of the education sector in Nigeria: an evaluation", Review of Public Administration and Management, Vol. 3 No. 5, pp. 147-160.

Ortega, F. and Peri, G. (2009), "The Causes and Effects of International Migrations: evidence from OECD Countries 1980-2005”, NBER Working Paper Series (Working Paper 14833), Cambridge, MA.

Oster, E., Shoulson, I. and Dorsey, E. (2013), "Limited life expectancy, human capital, and health investments", American Economic Review, Vol. 103 No. 5, doi: 10.1257/aer.103.5.1977.

Perpetua, O.N., Chimaobi, I.C. and Jackson, J. (2019), "Economic recession and migration: the case of Nigeria", Nnamdi Azikiwe University A wka Journal of Sociology, Vol. 6 No. 1.

Pesaran, M., Shin, Y. and Smith, R. (2001), "Bounds testing approaches to the analysis of level relationships", Journal of Applied Econometrics, Vol. 16 No. 3, pp. 289-326.

Robinson, A. and Florence, I. (2016), "Education and human capital development in Nigeria: the way forward", Journal of Resourcefulness and Distinction, Vol. 12 No. 1, pp. 56-68.

Roman, M. and Vasilescu, M. (2016), "Explaining the migration intentions of Romanian youth: Are teenagers different”, Romanian Statistical Review, Vol. 64 No. 4, pp. 69-86.

Sapkota, J. (2014), "Access to infrastructure and human development: cross-country evidence”, in Kato, H. (Ed.), Perspectives on the Post-2015 Development Agenda, JICA Research Institute, Tokyo.

Sen Nag, O. (2017), "Countries with the highest life expectancy in Africa", WorldAtlas, available at: worldatlas.com/articles/countries-with-the-highest-life-expectancy-in-africa.html (accessed 10 April 2020).

Shafique, A. (2017), "An inquiry into determinants of brain drain; importance of lingual proximities", in Koç, S. et al. (Eds), Economic Issues: Crises, Finance and Agriculture, Ijopec Publication, London.

Shahbaz, M., Shafiullah, M. and Mahalik, M. (2019), "The dynamics of financial development, globalization, economic growth and life expectancy in Sub-Saharan Africa", Australian Economic Papers, doi: 10.1111/1467-8454.12163.

Shuaibu, M. and Oladayo, P. (2016), "Determinants of human capital development in Africa: a panel data analysis", Oeconomia Copernicana, Vol. 7 No. 4, pp. 523-549.

Simkovic, M. (2013), "Risk-Based student loans", Washington and Lee Law Review, Vol. 70 No. 1, pp. 527-530.

Stanojoska, A. and Petrevski, B. (2012), "Theory of push and pull factors: a new way of explaining the old", available at: www.researchgate.net/publication/ 283121360_THEORY_OF_PUSH_AND_PULL_FACTORS_A_NEW_WAY_OF_ EXPLAINING_THE_OLD\#fullTextFileContent (accessed 30 April 2020).

Tabassum, S., Quddoos, Yaseen, A. and Sardar, M.A. (2017), "The relationship between capital flight, labour migration, and economic growth", European Online Journal of Natural and Social Sciences, Vol. 6 No. 4, pp. 594-600.

Human capital flight

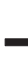


JHASS

4,1

20

Thinh, H. (2017), "Migration and education in Vietnam: opportunities and challenges", Advanced Science Letters, Vol. 23 No. 3, pp. 2166-2168.

Van Hear, N., Bakewell, O. and Long, K. (2017), "Push-pull plus: reconsidering the drivers of migration", Journal of Ethnic and Migration Studies, Vol. 44 No. 6, pp. 927-944, doi: 10.1080/ 1369183x.2017.1384135.

\section{Further reading}

Consterdine, E. (2019), "Youth mobility scheme: the panacea for ending free movement?", National Institute Economic Review, Vol. 248 No. 1, pp. R40-R48.

Michael, D. and Joseph, A. (2019), "Assessing the relationships between human capital, innovation, and technology adoption: Evidence from Sub-Saharan Africa", Technological Forecasting and Social Change, 12, 24-33.

Ogede, J. (2020), "Modelling inclusiveness of growth in Nigeria. What are the roles of remittances and institutional quality?", The Journal of Accounting and Management, Vol. 9 No. 3, pp. 44-57.

Olutayo, A. (2016), "Democracy, funding of higher education and students' 'Brain drain' in Nigeria: development implications for now and the future", Journal of Management and Social Sciences, Vol. 5 No. 2, pp. 1-14.

Perpetua, O., Chimaobi, I. and Jackson, J. (2014), "Economic recession and migration: the case of Nigeria”, Nnamdi Azikiwe University Awka Journal of Sociology, Vol. 6 No. 1, pp. 1-12.

Weichselbaumer, D. (2016), "Discrimination against migrant job applicants in Austria: an experimental study”, German Economic Review, Vol. 18 No. 2, pp. 237-265, doi: 10.1111/geer.12104.

\section{Corresponding author}

Oluwaseyi Popogbe can be contacted at: popogbeseyi@gmail.com

For instructions on how to order reprints of this article, please visit our website: 